\title{
Wildlife in Urban Landscapes: Use of Golf Course Ponds by Wetlands Birds 1
}

\section{LeAnn White and Martin B. Main ${ }^{2}$}

\section{Introduction}

As development associated with urban growth continues to alter and degrade natural habitats, created habitats in urbanized landscapes may become increasingly important for the conservation of wildlife. Unlike many types of developed landscapes, golf courses usually include large amounts of green space. Therefore, golf courses may provide unique opportunities for creating wildlife habitat in urbanized landscapes. Created wetlands in the form of ponds and other water hazards can provide habitat for a diverse array of wetland-dependent species, particularly birds. This document describes the numbers and types of wetland-dependent birds, collectively referred to as "waterbirds," recorded using golf course ponds during a study of 183 ponds on 12 golf courses over a 2-year period in Southwest Florida. We also provide recommendations based on this study that can be implemented to improve habitat on golf course and stormwater retention ponds for waterbirds.

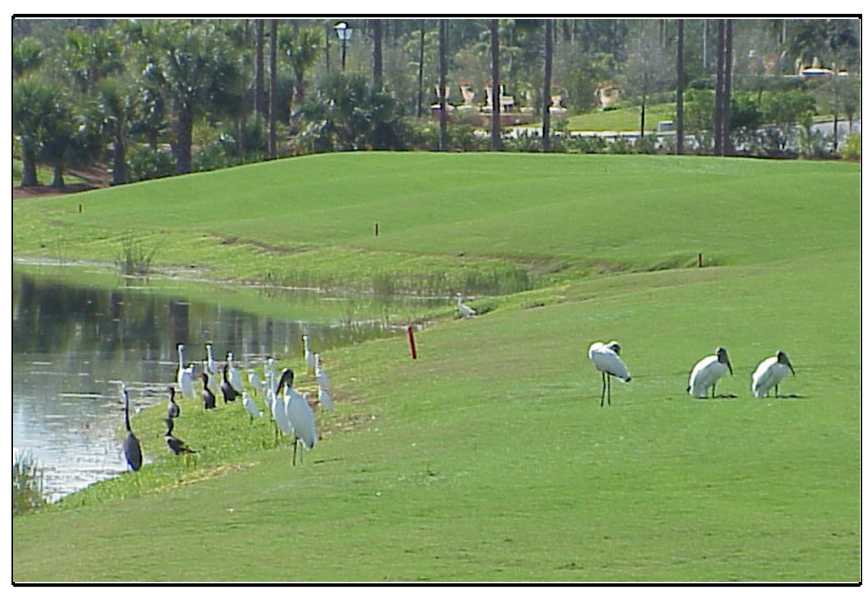

Figure 1. Wood storks, cormorants, herons, and egrets are among waterbirds observed at a golf course pond in Southwest Florida. Credits: UF/IFAS

\section{Waterbird Use of Golf Course Ponds in Southwest Florida}

This study focused on aquatic birds which are wetland-dependent species. Members from the following orders of birds were surveyed: Ciconiiformes, Gruiformes, Pelecaniformes, Anseriformes, Podicipediformes, Coraciiformes, and Charadriformes. Birds from these orders represent a

1. This document is WEC 188, one of a series of the Department of Wildlife Ecology and Conservation, Florida Cooperative Extension Service, Institute of Food and Agricultural Sciences (IFAS), University of Florida. Publication date: December 2004. Please visit the EDIS Web site at http://edis.ifas.ufl.edu.

2. C. LeAnn White, Graduate Student, University of Florida/IFAS, Department of Wildlife Ecology and Conservation, Gainesville, FL; and Martin B. Main, University of Florida/IFAS, Department of Wildlife Ecology and Conservation, Southwest Florida Research and Education Center, Immokalee, FL.

The Institute of Food and Agricultural Sciences (IFAS) is an Equal Employment Opportunity - Affirmative Action Employer authorized to provide research, educational information and other services only to individuals and institutions that function without regard to race, creed, color, religion, age, disability, sex, sexual orientation, marital status, national origin, political opinions or affiliations. For information on obtaining other extension publications, contact your county Cooperative Extension Service office. Florida Cooperative Extension Service / Institute of Food and Agricultural Sciences / University of Florida / Larry R. Arrington, Interim Dean 
variety of bird sizes, morphology, foraging behaviors, and habitat preferences. From an ecological perspective, a useful approach is to group different species by their foraging behaviors because these behaviors strongly influence habitat preferences. We identified six foraging guilds defined by major foraging techniques, food types, and substrates for each species (Table 1). Foraging guilds also provide a useful approach for evaluating the influence of habitat changes on community dynamics and allow for the development of management recommendations to benefit groups of birds rather than individual species.

During January-April 2001 and 2002, 10,474 waterbirds were observed during surveys of 183 ponds on 12 golf courses (Table 2). We observed 42 species of waterbirds (30 in 2001 and 40 in 2002) over both years. Although a large number of birds and species were recorded, the low densities of birds ( 1 bird per acre) suggests there is opportunity to increase the habitat value of golf course ponds to waterbirds.

Observations during our study revealed that waterbirds primarily used golf course ponds for foraging activities, and nesting was the least common behavior recorded. The most abundant waterbird guild recorded using golf course ponds was the Diving Birds guild ( $\mathrm{n}=4,588$ observations). The two most abundant species from this guild were double-crested cormorants (Phalacrocorax auritus) and anhingas (Anhinga anhinga). Anhingas (in 2001) and double-crested cormorants (in 2002) were also observed on more study ponds than any other species (Table 2). The second most frequently observed guild was Open Water Waders $(\mathrm{n}=3,040)$, with little blue herons (Egretta caerulea) most abundant over the 2-year study period. The Dense Vegetation Wader guild was observed least frequently $(n=119)$.

\section{Habitat Preferences and Recommendations}

The wide range of habitat variables selected by each foraging guild indicates that providing a diversity of habitat features among ponds within a golf course would provide the greatest benefits to the largest number of species. To accomplish this goal, ponds could be managed as a wetland complex, whereby different ponds or sections of ponds are enhanced or modified to represent different types of habitat. For example, creating areas along ponds that have dense shrub cover would benefit dense-vegetation waders; trees can provide roosting sites; and the creation of shallow foraging areas will benefit wading birds and numerous other species. Not all pond features were attractive to waterbirds. For example, man-made structures, such as walls and ledges around pond perimeters, were avoided by some species (Dipping and Dabbling Foragers), probably because these structures impeded movement into and out of the water.

Habitat management designed to benefit waterbirds may also provide cost savings for the golf course. Maintenance problems associated with wet areas along edges of ponds may be ideal for modifications (e.g., increasing the littoral zone) to benefit waterbirds while simultaneously reducing management costs. Consequently, opportunities likely exist on many golf course ponds to improve habitat for waterbirds, while providing financial savings and generating positive public relations for practices that provide benefits to wildlife.

\section{Acknowledgements}

This research was supported by the Florida Agricultural Experiment Station and grants from the United States Golf Association, the National Fish and Wildlife Foundation Wildlife Links program, and the Bonita Bay Group. We thank K. M. Portier for statistical guidance and P. C. Frederick and H. F. Percival for their contributions to the development of this study. We thank K. Miller and M. Voigt for their assistance in the field as well as Bonita Bay and Watermark Communities, Inc., for access to their courses and for their logistical support.

\section{Additional Sources of Information}

De Graaf, R. M., N. G. Tilghman, and S. T. Anderson. 1985. Foraging guilds of North American birds. Ecological Management 9: 493-536. 
Ehrlich, P. R., D. S. Dobkin, and D. Wheye.

1988. The Birder's Handbook. NY: Simon Schuster, Inc.

Gawlik, D. E. 2002. The effects of prey availability on the numerical response of wading birds. Ecological Monographs 73: 329-346.

Hoyer, M. V., and D. E. Canfield, Jr. 1990. Limnological factors influencing bird abundance and species richness on Florida lakes. Lake and Reservoir Management 6: 133-141.

Kushlan, J. A. 1978. Feeding ecology of wading birds. In: S. Winckler, editor. Wading Birds.

National Audubon Society. Research Report No. 7 , New York, New York. P. 249-97.

Kushlan, J. A. 2000. Research and information needs for heron conservation. In H. Hafner, editor. Heron conservation. San Diego, CA: Academic Press. P. 331-42.

Weller, M. W. 1999. Wetland Birds: Habitat Resources and Conservation Implications. Cambridge, UK: University Press.

White, C. L. 2003. Waterbird Use of Golf Course Ponds in Southwest Florida. M.S. Thesis, University of Florida, Wildlife Ecology and Conservation Department, Gainesville, FL. 
Table 1. Foraging guilds with general description of foraging techniques used for classification and representative species for each guild.

\begin{tabular}{||c|l|l||}
\hline Foraging Guild & \multicolumn{1}{|c||}{ General Description } & \multicolumn{1}{|c||}{ Species } \\
\hline Diving Birds & $\begin{array}{l}\text { Forage in a variety of water depths, but } \\
\text { were generally observed in open water }\end{array}$ & $\begin{array}{l}\text { Grebes, cormorants, anhingas, mergansers, } \\
\text { scaup, ruddy and ring-necked ducks }\end{array}$ \\
\hline Open Water Waders & $\begin{array}{l}\text { Forage in shallow water with low density } \\
\text { vegetation }\end{array}$ & Herons, egrets, ibises, storks, cranes \\
\hline Dense Vegetation Waders & $\begin{array}{l}\text { Forage in shallow water surrounded by } \\
\text { dense vegetation }\end{array}$ & Night and green herons, bitterns \\
\hline Dipping/Dabbling Foragers & $\begin{array}{l}\text { Forage by surface dipping or dabbing in } \\
\text { shallow water }\end{array}$ & Mottled ducks, blue-wing teal, moorhens, coots \\
\hline Moist-soil Foragers & $\begin{array}{l}\text { Forage in muddy or moist-soil areas } \\
\text { along the shoreline }\end{array}$ & $\begin{array}{l}\text { Sandpipers, yellowlegs, stilts, willets, killdeer, } \\
\text { snipes, gulls }\end{array}$ \\
\hline Aerial Piscivores & $\begin{array}{l}\text { Generally use perches to search for prey } \\
\text { and then dive from a height to capture } \\
\text { prey }\end{array}$ & Terns, kingfishers, eagles, osprey, pelicans \\
\hline
\end{tabular}




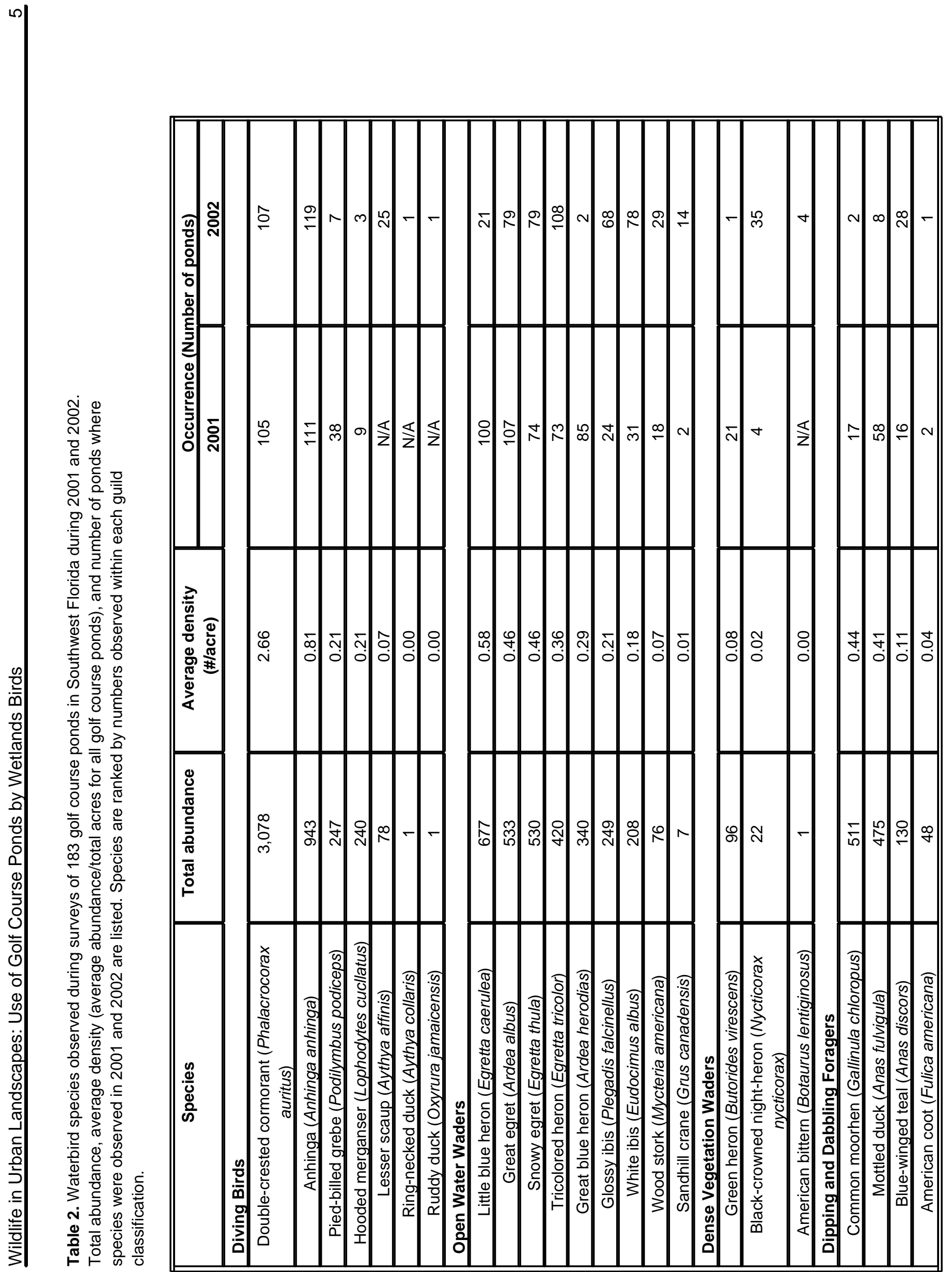




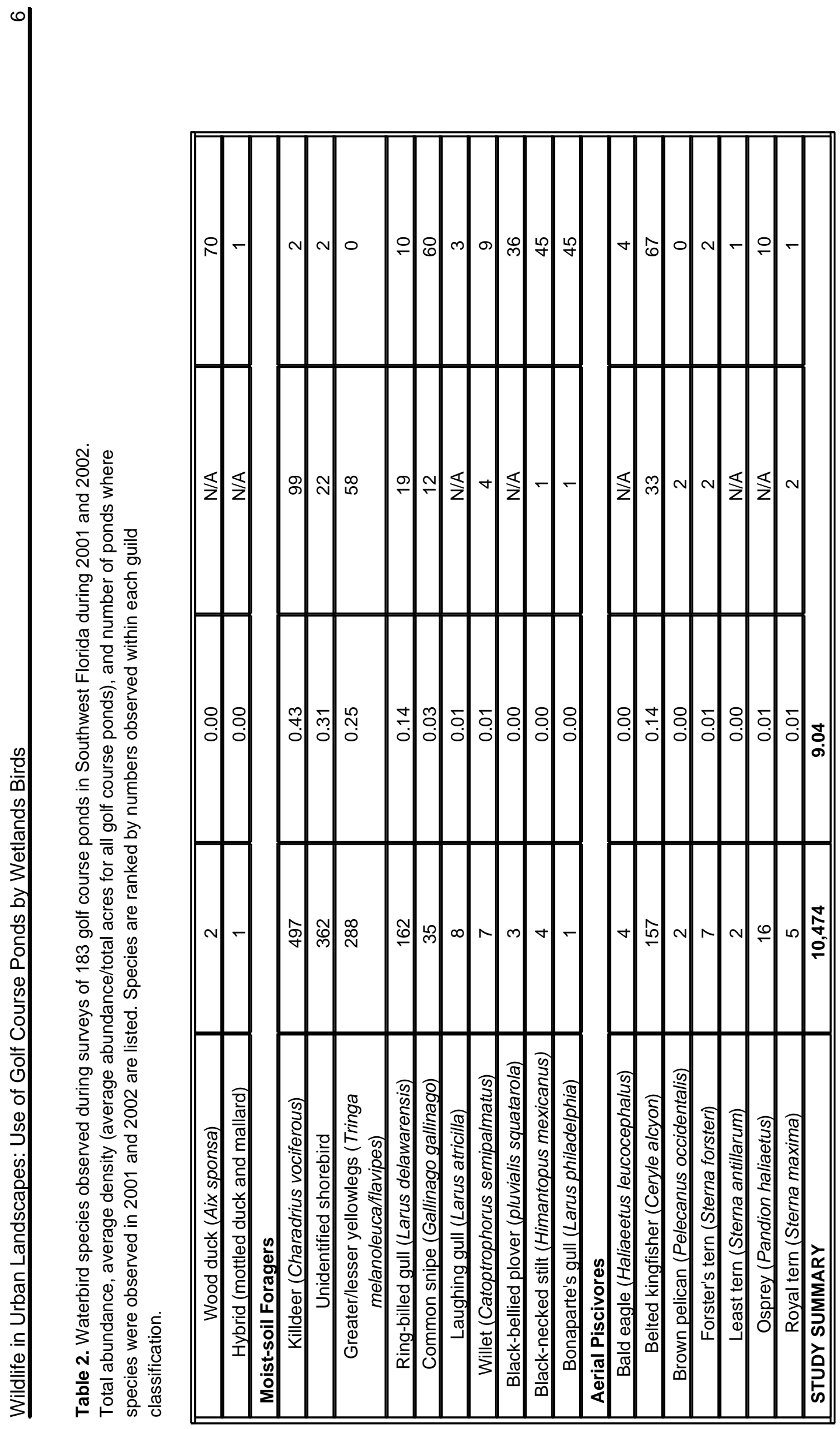

